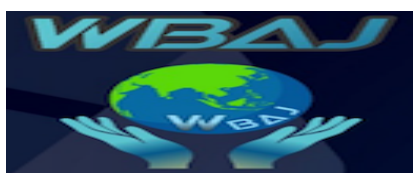

Volume 1 Issue 1, Juni 2019

http:// ejournal.unsub.ac.id/index.php/bisnis

\title{
Kinerja Seksi Usaha Ekonomi Masyarakat \\ Dalam Pemberdayaan Pengelola Badan Usaha Milik Desa (BUMDES) Di Kabupaten Subang
}

\author{
Yeni Nuraeni \\ Dinas Koperasi, Perdagangan dan Perindustrian (DKUPP) \\ Kabupaten Subang \\ ynuraeni30@yahoo.com
}

\begin{abstract}
Abstrak
Seksi Usaha Ekonomi Masyarakat dalam Pemberdayaan Pengelola Badan Usaha Milik Desa (BUMDES) di Kabupaten Subang dalam hubungannya dengan teori kinerja organisasio yaitu produktifitas, kualitas layanan, responsivitas, responsibilitas dan akuntabilitas. Hasil penelitian menunjukan bahwa Kinerja Seksi Usaha Ekonomi Masyarakat dalam Pemberdayaan Pengelola Badan Usaha Milik Desa (BUMDES) di Kabupaten Subang secara umum belum optimal. Hal ini dapat dilihat dari jumlah BUMDES yang belum terealisasi sesuai target, 30\% dari 78 BUMDES yang terdata di 30 Kecamatan dalam kondisi tidak berjalan, pelaksanaan monitoring dan evaluasi dilakukan sementara waktu serta keterlambatan dalam pelaporan.
\end{abstract}

Kata Kunci : Kinerja Organisasi, BUMDES

\begin{abstract}
This research and writing discusses matters relating to the Performance of the Community Economic Business Section in Empowering the Management of Village-Owned Enterprises (BUMDES) in Subang Regency in relation to the theory of public organization perpormance namely productivity, service quality, responsiveness, responsibility and accountability.

The results of the study showed that the Performance of the Community's Economic Business Section in Empowering Managers of Village-Owned Enterprises (BUMDES) in Subang district in general was not optimal. This can be seen from the number of BUMDES that have not been realized according to the target, 30\% of the 78 BUMDES recorded in 30 subdistricts were not functioning, the monitoring and evaluation carried out temporarily as well as delays in reporting.
\end{abstract}

Keywords: Organizational Performance, BUMDES 


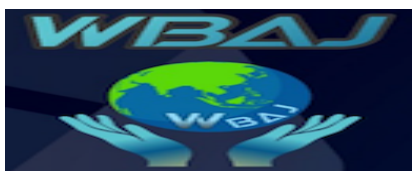

Volume 1 Issue 1, Juni 2019

http:/ / ejournal.unsub.ac.id/index.php/bisnis

\section{Pendahuluan}

Kinerja (performance) sudah menjadi kata populer yang sangat menarik dalam pembicaraan manajemen publik. Konsep kinerja pada dasarnya dapat dilihat dari dua segi, yaitu kinerja pegawai (per-individu) dan kinerja organisasi. Kinerja adalah gambaran mengenai tingkat pencapaian pelaksanaan tugas dalam suatu organisasi, dalam upaya mewujudkan sasaran, tujuan, misi, dan visi organisasi tersebut. Kinerja merupakan suatu fungsi dari motivasi dan kemampuan untuk menyelesikan tugas atau pekerjaan. Seseorang sepatutnya memiliki derajat kesediaan dan tingkat kemampuan tertentu. Kesediaan dan keterampilan seseorang tidaklah cukup efektif untuk mengerjakan sesuatu tanpa pemahaman yang jelas tentang apa yang akan dikerjakan dan bagaimana mengerjakannya. Sedangkan pengukuran kinerja yaitu pengukuran atas keberhasilan atau kegagalan pelaksanaan kegiatan organisasi, program, atau kebijakan yang sesuai dengan sasaran dan tujuan yang telah ditetapkan sebelumnya dalam rangka mewujudkan visi-misi organisasi. Tujuan pengukuran kinerja organisasi sektor publik yaitu untuk mengetahui tingkat ketercapaian tujuan organisasi, memberikan atau menyediakan sarana pembelajaran bagi pegawai, memperbaiki kinerja periode berikutnya. Dinas Pemberdayaan Masyarakat dan Desa Kabupaten Subang, sebagai Dinas yang harus memberdayakan masyarakat, dan pengelola Program di tingkat Desa/Kelurahan, maka tidak akan lepas dari bagaimana memberdayakan pemerintahan desa/kelurahan juga sebagai wadah terdekat pelayanan masyarakat desa. Pemberdayaan masyarakat, yakni memampukan dan memandirikan masyarakat, maka upaya untuk mewujudkan hal tersebut dilaksanakan melalui intervensi berbagai program pembangunan, baik program sktoral, program regional/daerah dan program pusat yang ditunjukan ke desa/kelurahan dengan melibatkan peran aktif masyarakat dalam seluruh proses pembangunan disamping itu dalam rangka meningkatkan kemandirian masyarakat dilakukan upaya penataan sistem pengelola pembangunan dan pengembangan kelembagaan masyarakat, agar masyarakat desa dapat berperan aktif secara optional dalam seluruh proses pembangunan desa.

BUMDES di Kabupaten Subang sendiri diatur dengan Peraturan Bupati Subang No 13 tahun 2017 tentang pembentukan dan pengelolaan Badan Usaha Milik Desa. Berdasarkan Perbub Kabupaten Subang No 13 tahun 2017 tentang Pembentukan dan Pengelolaan Badan Usaha Milik Desa, BUMDES adalah badan usaha yang seluruh atau sebagian besar modalnya dimiliki oleh desa melalui penyertaan secara langsung yang berasal dari kekayaan desa yang dipisahkan guna mengelola aset, jasa pelayanan dan usaha lainnya untuk sebesar-besarnya kesejahteraan masyarakat desa. Pembentukan BUMDES bertujuan untuk meningkatkan perekonomian desa, mengoptimalkan aset desa agar bermanfaat untuk kesejahteraan masyarakat desa, meningkatkan usaha masyarakat dalam pengelolaan potensi ekonomi desa, mengembangkan rencana kerja sama usaha antar desa dan atau dengan pihak ketiga, menciptakan peluang dan jejaring pasar yang mendukung kebutuhan layanan umum masyarakat desa, membuka lapangan kerja, meningkatkan kesejahteraan masyarakat melalui perbaikan pelayanan umum pertumbuhan dan pemerataan ekonomi desa dan meningkatkan pendapatan masyarakat desa, pendapatan asli desa dan pertumbuhan ekonomi desa. Badan 
Usaha Milik Desa (BUMDES) adalah badan usaha yang seluruh atau sebagian modalnya dimiliki oleh desa. BUMDES merupakan pengembangan ekonomi yang dibentuk pemerintah desa yang dikelola dengan semangat kekeluargaan dan gotong royong. Dalam mengelola segala potensi ekonomi, kelembagaan, SDA, serta SDM dalam rangka meningkatkan kesejahteraan masyarakat desa. BUMDES salah satu dari 4 (empat) program Kementrian Desa PDTT. Untuk itu pemerintah mendorong setiap desa untuk mendirikan BUMDES. Karena BUMDES diyakini akan membawa perubahan di bidang ekonomi dan sosial di masa sekarang dan yang akan datang.

Kabupaten Subang terbagi menjadi 30 Kecamatan, 8 Kelurahan dan 245 Desa. Diantara banyaknya desa yang ada di Kabupaten Subang, terdapat beberapa desa yang sudah memiliki Badan Usaha Milik Desa (BUMDES) yang dikelola dan dijalankan dengan baik, belum berkembang dan masih ada desa yang belum memiliki BUMDES. Padahal Kabupaten Subang memiliki banyak sekali potensi sumber daya alam untuk produk unggulan yang belum tergarap dan bisa meningkatkan kesejahteraan perekonomian desa. Salah satu penyebab tidak berkembangnya BUMDES saat ini adalah Sumber Daya Manusia (SDM), baik itu kepala desa maupun pengelola BUMDES. Kebanyakan Kepala Desa masih kurang memahami pentingnya BUMDES akibatnya butuh usaha keras untuk memahami BUMDES yang lebih bertumpu pada masalah kewirausahaan. Pengelola BUMDES, masih kurang kemampuan dalam mengelolanya, pengurusnya belum jalan, belum siap jika merintis dari nol, gaji karena pengelola BUMDES tidak digaji oleh pemerintah sehingga SDM-nya tidak benar-benar dalam menjalankan BUMDES. BUMDES yang ada di desa adalah organisasi yang diatur oleh peraturan desa sehingga BUMDES tersebut dipimpin bukan dari pihak desa, tapi pihak lain yang mempunyai jiwa enterpreneur. Karena BUMDES pengelolanya (manager) tidak boleh dijabat oleh Kepala Desa itu sendiri, sehingga perlu diisi orang yang kompeten dibidangnya. Selain itu kebanyakan masyarakat tidak mengetahui apa itu BUMDES, karena itulah BUMDES ada yang sudah eksis, belum eksis dan masih dalam proses pembentukan.

Dinas Pemberdayaan Masyarakat dan Desa mencatat, jumlah BUMDES di Kabupaten Subang sebanyak 154 dan 91 belum memiliki BUMDES atau sekitar $62,85 \%$ yang telah memiliki BUMDES itupun ada yang sudah eksis maupun sedang dalam proses pembentukan, penyertaan modal dan pengembangan unit usaha. Kebanyakan BUMDES gedungnya masih menyatu dengan kantor desa. Jenis usaha BUMDES di Kabupaten Subang yaitu mulai dari perdagangan/jasa, simpan pinjam, pertanian, pariwisata, agen bank, transportasi dan kerajinan. (Sumber: Bidang Pemberdayaan Usaha Ekonomi Masyarakat, 2018). Walaupun sudah melebihi target yang telah ditentukan, namun dari angka tersebut pada kenyataannya masih ada BUMDES yang belum berkembang secara optimal dan sesuai harapan. Seperti masih ada BUMDES yang tidak melakukan aktivitas kerja, kurangnya kemampuan Sumber Daya Manusia (SDM) pengelola BUMDES, pengelolaannya belum benar, terlebih kepengurusan BUMDES ada yang diisi oleh aparat desa. Perlu adanya peran pemerintah sebagai pengenggerak untuk menyadarkan masyarakat akan pentingnya BUMDES untuk usaha mereka. Berdasarkan data yang penulis dapat, diperoleh gambaran mengenai kinerja Bidang Pemberdayaan Usaha Ekonomi Masyarakat dalam Pemberdayaan BUMDES di Kabupaten Subang belum 


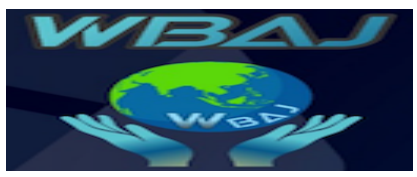

Volume 1 Issue 1, Juni 2019

http:// ejournal.unsub.ac.id/index.php/bisnis

sepenuhnya berjalan dengan baik. Hal ini bisa dilihat dari tingkat produktifitas ditunjukan oleh jumlah Desa yang memiliki BUMDES 154 dari 245 Desa yang ada di Kabupaten Subang. dikarenakan kurangnya SDM di bidang pemberdayaan usaha ekonomi masyarakat. Sedangkan target di tahun 2019 program pengembangan Bumdes mengharapkan setiap desa harus punya minimal satu Bumdes agar dapat meningkatkan pendapatan dan perekonomian masyarakat dan desa, walupun memang tergantung ada atau tidaknya potensi yang dimiliki desa tersebut. Sementara di Kabupaten Subang dari 30 Kecamatan baru ada 5 Kecamatan yang semua desanya memiliki BUMDES yaitu Kecamatan Jalancagak, Ciater, Serangpanjang, Pagaden dan Cipunagara. Dan diketahui bahwa 23 dari 78 BUMDES yang terdata di 30 Kecamatan dalam kondisi tidak berjalan penyebabnya masih kurangnya kemampuan Sumber Daya Manusia (SDM) di internal bumdes terkait.

\section{Kerangka Teori}

\section{Kinerja}

Kinerja (performance) sudah menjadi kata popular yang sangat menarik dalam pembicaraan manajemen publik. Konsep kinerja pada dasarnya dapat dilihat dari dua segi, yaitu kinerja pegawai (per-individu) dan kinerja organisasi. Kinerja adalah gambaran mengenai tingkat pencapaian pelaksanaan tugas dalam suatu organisasi, dalam upaya mewujudkan sasaran, tujuan, misi, dan visi organisasi tersebut (Moeheriono 2014:95). Konsep kinerja (Performance) dapat didefinisikan sebagai sebuah pencapaian hasil atau degree of accomplishtment (Moeheriono dalam IKU 68:2011). Pertanyaan Smith dikutip Sedarmayanti (2001:50), mengungkapkan bahwa kinerja adalah : "Output drive from process, human or otherwise (Kinerja merupakan hasil atau keluaran dari suatu proses)". Menurut Widodo dalam Pasolong (2011:175) "Kinerja adalah melakukan suatu kegiatan dan menyempurnakannya sesuai dengan tanggungjawabnya dengan hasil seperti yang diharapkan". Menurut Prawirosentono dalam Pasolong (2011:176) mengemukakan bahwa : "Kinerja adalah hasil kerja yang dapat dicapai oleh seseorang atau kelompok orang dalam suatu organisasi, sesuai dengan wewenang dan tanggung jawab masing-masing, dalam rangka upaya mencapai tujuan organisasi bersangkutan secara legal, tidak melanggar hukum dan sesuai dengan moral maupun etika". Dalam kaitan ini, seperti yang dikemukakan oleh Moeheriono (2014:95) menyatakan bahwa : "Kinerja merupakan gambaran mengenai tingkat pencapaian pelaksanaan suatu program kegiatan atau kebijakan dalam mewujudkan sasaran, tujuan, visi dan misi organisasi yang dituangkan melalui perencanaan strategis suatu organisasi". Menurut Bernardin (2001:143) menyatakan bahwa "kinerja merupakan catatan hasil yang dihasilkan atas fungsi pekerjaan tertentu atau aktivitas-aktivitas selama priode waktu tertentu". Sedangkan menurut Ningsih dalam Ihyaul (2009:19) menyatakan bahwa "kinerja merupakan aktifitas atau proses yang mengubah input menjadi output kemudian menjadi outcome, misalnya kesesuaian program atau aktivitas dengan hokum, peraturan, dan pedoman yang berlaku, atau standar proses yang telah ditetapkan". Kinerja dalam sebuah organisasi merupakan salah satu unsur yang tidak dapat dipisahkan dalam menjalankan tugas organisasi. 


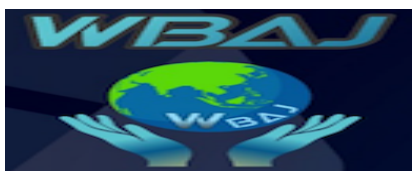

Volume 1 Issue 1, Juni 2019

http:/ / ejournal.unsub.ac.id/index.php/bisnis

Berdasarkan uraian diatas maka dapat disimpulkan bahwa kinerja organisasi adalah hasil kerja secara kualitas dan kuantitas yang dicapai oleh suatu oraganisasi pemerintahan sesuai dengan aturan hukum, serta standar kerja yang telah ditetapkan oleh organisasi tersebut. Selain itu juga suatu hasil yang dicapai oleh organisasi dalam upaya mewujudkan visi, misi, strategi, dan sasaran program di suatu organisasi pemerintahan. Hasil kerja yang dicapai oleh suatu instansi dalam menjalankan tugasnya dalam kurun waktu tertentu, baik yang terkait dengan input, output, outcome, benefit, maupun impact dengan tanggung jawab dapat mempermudah arah penataan organisasi. Adanya hasil kerja yang dicapai oleh instansi dengan penuh tanggung jawab akan tercapai peningkatan kinerja yang efektif dan efisien.

\section{Manajemen Kinerja}

Menurut Mahmudi (2013:5) “manajemen kinerja adalah proses yang sistematik, artinya untuk memperbaiki kinerja diperlukan langkah-langkah atau tahap-tahap yang terencana dengan baik". Proses perbaikan kinerja bukan merupakan kerja jangka pendek, melainkan merupakan proses evolutif yang berjangka panjang. Perubahan budaya memerlukan waktu yang lama. Demikian juga melakukan perubahan budaya kinerja memerlukan perencanaan yang matang, holistic dan jangka panjang. Menurut Wibowo (2010 :7) manajemen kinerja adalah menejemen tentang menciptakan hubungan dan memastikan komunikasi yang efektif. Manajemen kinerja memfokuskan pada apa yang diperlukan oleh organisasi, pemimpin, dan pegawai untuk berhasil. Manajemen kinerja adalah tentang bagaimana kinerja dikelola untuk memperoleh hasil sesuai dengan tujuan yang telah ditetapkan. Sedangkan menurut Bacal (Wibowo, 2010 : 8) memandang manajemen kinerja sebagai proses komunikasi yang dilakukan secara terus-menerus dalam kemitraan antara pegawai dengan atasan langsungnya. Proses komunikasi merupakan suatu system, memiliki sejumlah bagian yang semuanya harus diikutsertakan, apabila manajemen kinerja ini hendak memberikan nilai tambah bagi organisasi, pemimpin dan pegawai. Menurut Castello (1994: 6), manajemen kinerja mendukung tujuan menyeluruh organisasi dengan mengaitkan pekerjaan dari setiap pegawai dan pemimpin pada misi keseluruhan dari unit kerjanya. Seberapa baik kita mengelola kinerja bawahan akan secara langsung mempengaruhi tidak hanya kinerja masing-masing pekerja secara individu dan unit kerjanya, tetapi juga kinerja seluruh organisasi.

\section{Kinerja Organisasi}

Kinerja organisasi merupakan indikator tingkatan prestasi yang dapat dicapai dan mencerminkan keberhasilan suatu organisasi, serta merupakan hasil yang dicapai dari perilaku anggota organisasi. Kinerja Bisa juga dikatakan sebuah hasil (output) dari suatu proses tertentu yang dilakukan oleh seluruh komponen organisasi terhadap sumber-sumber tertentu yang digunakan (input). Selanjutnya, kinerja juga merupakan hasil dari serangkaian proses kegiatan yang dilakukan untuk mencapai tujuan tertentu organisasi. Bagi suatu organisasi, kinerja merupakan hasil dari kegiatan kerjasama diantara anggota atau komponen organisasi dalam rangka mewujudkan tujuan organisasi. Kinerja Organsasi 


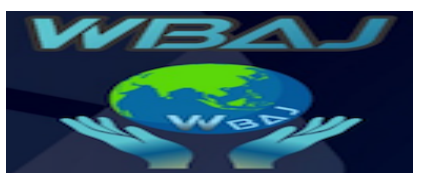

Volume 1 Issue 1, Juni 2019

http:// ejournal.unsub.ac.id/index.php/bisnis

mempunyai banyak pengertian. Menurut Mahmudi (2005:22) mengemukakan bahwa: "kinerja organisasi pada dasarnya merupakan tanggungjawab setiap individu yang bekerja dalam organisasi. Apabila dalam organisasi setiap individu bekerja dengan baik, berprestasi, bersemangat dan memberikan konstribusi terbaik mereka terhadap organisasi, maka kinerja organisasi secara keseluruhan akan baik. Dengan demikian, kinerja organisasi merupakan cermin dari kinerja individu."

Selanjutnya menurut Rummler dan Branche (dalam Sudarmanto, 2009:7), kinerja organisasi merupakan pencapaian hasil (out-come) pada level unit analisis organisasi. Kinerja pada level ini terkait dengan tujuan organisasi, rancangan organisai dan manajemen organisasi. Pendapat lain dekemukakan oleh Wibawa (1992:64), Atmosudirdjo (1997:11), mengemukakan bahwa: "Kinerja organisasi adalah sebagai efektifitas organisasi secara menyeluruh untuk kebutuhan yang ditetapkan dari setiap sekelompok yang kemampuan melalui usaha-usaha yang sistematik dan meningkatkan kemampuan organisasi secara terus menerus untuk mencapai kebutuhan secara efektif". Artinya kinerja organisasi merupakan suatu capaian hasil kerja dalam kegiatan organisasi melalui aktifitas atau program yang telah direncanakan sebelumnya dengan seefektif mungkin melalui usaha-usaha yang terarah guna mencapai tujuan serta sasaran yang telah ditetapkan oleh suatu organisasi untuk mencapai kebutuhannya.Sedangkan pengertian kinerja organisasi menurut Surjadi (2009: 7), yaitu sebagai berikut: “Kinerja organisasi adalah totalitas hasil kerja yang dicapai suatu organisasi tercapainya tujuan organisasi berarti bahwa, kinerja suatu organisasi itu dapat dilihat dari tingkatan sejauh mana organisasi dapat mencapai tujuan yang didasarkan pada tujuan yang sudah ditetapkan sebelumnya". Artinya kinerja juga merupakan hasil dari totalitas serangkaian proses kegiatan yang dilakukan untuk mencapai tujuan tertentu organisasi. Bagi suatu organisasi, kinerja merupakan hasil kegiatan kerjasama diantara anggota atau komponen organisasi dalam rangka mewujudkan tujuan yang telah ditetapkan sebelumnya dalam organisasi.

Menurut Mahsun (2006 : 25) mengemukakan bahwa: "Kinerja organisasi adalah gambaran mengenai tingkat pencapaian pelaksanaan suatu organisasi/program/kebijakan dalam mewujudkan sasaran, tujuan, visi dan misi organisasi yang tertuang dalam Strategic Planning suatu organisasi." Artinya bahwa kinerja organisasi adalah seberapa jauh tingkatan kemampuan untuk melaksanakan tugas organisasi dalam pencapaian tujuan sesuai dengan kemampuan yang dimiliki dan program/kebijakan/visi dan misi yang telah ditetapkan sebelumnya. Berdasarkan definisi diatas mengenai pengertian kinerja organisasi dapat disimpulkan bahwa kinerja organisasi adalah penilaian terhadap seberapa jauh tingkatan kemampuan pelaksanaan tugas-tugas organisasi dalam rangka pencapaian tujuan sesuai dengan kemampuan yang dimiliki dan program/kebijakan/visi dan misi yang telah ditetapkan sebelumnya. Kinerja organisasi pun harus dilakukan secara legal yang berarti dalam melaksanakan tugas harus mengikuti aturan yang telah ditetapkan.

\section{Indikator Kinerja}

Indikator kinerja sangat diperlukan dalam suatu organisasi, baik itu organisasi publik maupun organisasi bisnis karena indikator kinerja sebagai alat 


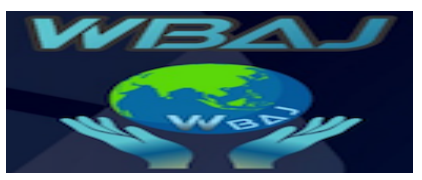

Volume 1 Issue 1, Juni 2019

http:// ejournal.unsub.ac.id/index.php/bisnis

ukur kinerja itu sendiri. Indikator kinerja menjadi kunci dalam mengelola kinerja di semua level organisasi, baik di level strategis maupun oprasional atau teknis. Peran indikator kinerja bagi organisasi sektor publik adalah memberikan tanda atau rambu-rambubagi pimpinan dan pihak luar untuk mengukur sesuatu. Dalam pengembangan indikator kinerja, harus diperhatikan berbagai aspek. Indikator kinerja yang dihasilkan tidak memberikan gambaran kinerja yang terdistorsi. Sistem pengukuran kinerja yang efektif dan tidak terdistorsi diperoleh melalui desain indikator kinerja yang baik.Menurut Bernadin dalam Sudarmanto (2001:12-13), mengemukakan ada 6 kriteria dasar atau dimensi untuk mengukur kinerja, yaitu :

1) Quality, terkait dengan proses atau hasil mendekati sempurna atau ideal dalam memenuhi maksud atau tujuan.

2) Quantity,yaitu terkait dengan satuan jumlah atau kuantitas yang dihasilkan

3) Timelines, terkait dengan waktu yang diperlukan dalam menyelesaikan aktivitas atau menghasilkan.

4) Cost-effectiveness terkait dengan tingkat penggunaan sumber-sumber organisasi (orang, uang, material, teknologi) dalam mendapatkan atau memperoleh hasil atau pengurangan pemborosan dalam penggunaan sumber-sumber organisasi.

5) Need for Supervision, terkait dengan kemampuan individu dapat menyelesaikan pekerjaan atau fungsi-fungsi pekerjaan tanpa asistensi pimpinan atau intervensi pengawas pimpinan.

6) Interpersonal Impact, terkait dengan kemampuan individu dalam meningkatkan perasaan harga diri, keinginan baik, dan kerja sama diantara sesama pekerja atau pegawai.

Dengan demikian indikator kinerja dapat digunakan untuk mengevaluasi: Tahapan perencanaan, Tahapan pelaksanaan, Tahapan setelah kegiatan selesai dan berfungsi. Menurut Kumorotomo, 1996 (dalam Dwiyanto,2002) merumuskan 4 indikator penilaian terhadap kinerja organisasi, yaitu:

1) Efisiensi: menyangkut pertimbangan tentang keberhasilan pelayanan publik mendapatkan laba, memanfaatkan faktor-faktor produksi serta pertimbangan yang berasal dari rasionalitas ekonomi.

2) Efektivitas: menyangkut rasionalitas teknis, nilai, misi, tujuan organisasi serta fungsi agen pembangunan.

3) Keadilan: menyangkut distribusi dan alokasi layanan yang diselenggarakan oleh organisasi pelayanan publik.

4) Daya tanggap: daya tanggap terhadap kebutuhan vital masyarakat, dan dapat dipertanggungjawabkan secara transparan.

Menurut Moeheriono (2010:80) mengemukakan mengenai ukuran kinerja organisasi yaitu:

1) Efektif, indikator ini mengukur derajat kesesuaian output yang dihasilkan dalam mencapai sesuatu yang diinginkan.

2) Efisien, indikator ini mengukur derajat kesesuaian proses menghasilkan output dengan menggunakan biaya serendah mungkin.

3) Kualitas, indikator ini mengukur derajat kesesuaian antara kesesuaian produk yang dihasilkan dengan kebutuhan dan harapan. 


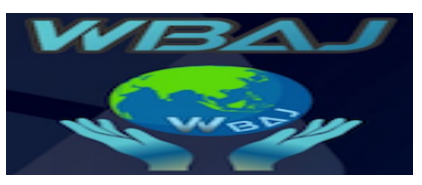

Volume 1 Issue 1, Juni 2019

http:// ejournal.unsub.ac.id/index.php/bisnis

4) Ketetapan waktu, indikator ini mengukur apakah pekerjaan telah diselesaikan secara benar dan tepat waktu.

5) Produktivitas, indikator ini mengukur tingkat produktivitas suatu organisasi. Menurut Dwiyanto (2012: 50-51) menggunakan beberapa kriteria untuk dijadikan pedoman dalam menilai kinerja organisasi publik antara lain sebagai berikut:

1) Produktivitas; Konsep produktivitas tidak hanya mengukur tingkat efisiensi, tetapi juga efektivitas pelayanan. Produktivitas pada umumnya dipahami secara umum sebagai rasio antara input dengan output.

2) Kualitas Layanan; Isu mengenai kualitas layanan cenderung menjadi penting dalam menjelaskan kinerja organisasi publik. Hal ini disebabkan adanya pandangan negatif yang terbentuk mengenai organisasi publik muncul karena ketidakpuasan masyarakat terhadap kualitas layanan yang diterima. Dengan demikian kualitas layanan dapat dijadikan indikator kinerja organisasi publik.

3) Responsivitas; Responsivitas adalah kemampuan organsiasi untuk mengenali kebutuhan masyarakat, menyusun agenda dan prioritas pelayanan, dan mengembangkan program-program pelayanan, dan mengembangkan program-program pelayanan publik sesuai dengan kebutuhan dan aspirasi masyarakat. Secara singkat responsivitas di sini menunjuk pada keselarasan antara program dan kegiatan pelayanan dengan kebutuhan dan aspirasi masyarakat. Responsivitas dimasukkan sebagai salah satu indikator kinerja karena responsivitas secara langsung menggambarkan kemampuan organisasi publik dalam menjalankan misi dan tujuannya, terutama untuk memenuhi kebutuhan masyarakat.

4) Responsibilitas; Responsibilitas menjelaskan apakah pelaksanaan kegiatan organisasi publik itu dilakukan sesuai dengan prinsip-prinsip administrasi yang benar atau sesuai dengan kebijakan organisasi, baik yang eksplisit maupun implisit. Oleh sebab itu itu, responsibilitas bisa saja pada suatu ketika berbenturan dengan reponsivitas.

5) Akuntabilitas; Akuntabilitas publik menunjuk pada seberapa besar kebijakan dan kegiatan organisasi publik tunduk pada para pejabat politik yang dipilih oleh rakyat. Dalam konteks ini, konsep akuntabilitas publik dapat digunakan untuk melihat seberapa besar kebijakan dan kegiatan organisasi publik tersebut konsisten dengan kehendak masyarakat banyak.

\section{Badan Usaha Milik Desa (BUMDES)}

Menurut Peraturan Bupati Subang Nomor 13 Tahun 2017 Badan Usaha Milik Desa (BUMDES) adalah badan usaha yang seluruh atau sebagian besar modalnya dimiliki oleh desa melalui penyertaan secara langsung yang berasal dari kekayaan desa yang dipisahkan guna mengelola aset, jasa pelayanan dan usaha lainnya untuk sebesar-besarnya kesejahteraan masyarakat desa. Pendirian Badan Usaha Milik Desa (BUMDES) dilandasi oleh:

1) Undang-Undang Republik Indonesia Nomor 6 Tahun 2014 tentang Desa.

2) Undang-Undang Nomor 23 Tahun 2014 tentang Pemerintahan Daerah.

3) Peraturan Pemerintah Nomor 43 Tahun 2014 tentang Peraturan Pelaksanaan. 


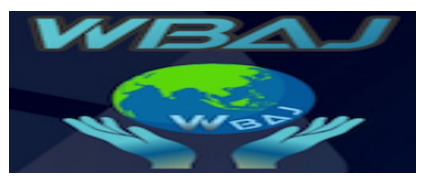

Volume 1 Issue 1, Juni 2019

http:// ejournal.unsub.ac.id/index.php/bisnis

4) Peraturan Mentri Desa, Pembangunan Daerah Tertinggal, dan Transmigrasi Nomor 4 Tahun 2015 tentang Pendirian, Pengurusan dan Pengelolaan, dan Pembubaran Badan Usaha Milik Desa.

5) Peraturan Daerah Kabupaten Subang Nomor 4 Tahun 2015 tentang Desa.

6) Peraturan Bupati Subang Nomor 13 Tahun 2017 tentang Pembentukan dan Pengelolaan Badan Usaha Milik Desa.

Ciri utama Badan Usaha Milik Desa (BUMDES) yaitu:

1) Badan Usaha ini dimiliki oleh desa dan dikelola bersama.

2) Modal usaha bersumber dari desa (51\%) dan masyarakat (49\%) melalui pernyataan modal (saham atau andil).

3) Oprasionalisasinya menggunakan falsafah bisnis yang bderakar dari budaya lokal.

4) Bidang usaha yang dijalankan berdasarkan potensi dan informasi pasar.

5) Keuntungan yang diperoleh ditunjukan untuk meningkatkan kesejahteraan anggota (penyerta modal) dalam masyarakat melalui kebijakan desa.

6) Difasilitasi oleh pemerintah, pemerintah propinsi, pemerintah kabupaten/kota, pemerintah desa.

7) Pelaksanaan oprasionalisasi dikontrol secara bersama oleh (Pemdes, BPD, Pemerintah Desa dan Anggota).

BUMDES sebagai suatu lembaga ekonomi modal usahanya dibangun atas inisiatif masyarakat dan menganut asas mandiri, ini berarti pemenuhan modal Bumdes harus bersumber dari masyarakat. Meskipun demikian tidak menutup kemungkinan Bumdes dapat mengajukan pinjaman modal kepada pihak luar seperti kepada pemerintah desa atau kepada pihak ketiga.

Pembentukan Badan Usaha Milik Desa (BUMDES) bertujuan:

1) Meningkatkan perekonomian desa.

2) Mengoptimalkan aset desa agar bermanfaat untuk kesejahteraan masyarakat desa.

3) Meningkatkan usaha masyarakat dalam pengelolaan potensi ekonomi desa.

4) Mengembangkan rencana kerja sama usaha antar desa dan/ atau dengan pihak ketiga.

5) Menciptakan peluang dan jaringan pasar yang mendukung kebutuhan layanan umum masyarakat desa.

6) Membuka lapangan kerja

7) Meningkatkan kesejahteraan masyarakat melalui perbaikan pelayanan umum, pertumbuhan dan pemerataan ekonomi desa.

8) Meningakatkan pendapatan masyarakat desa, pendapatan asli desa dan pertumbuhan ekonomi desa.

\section{Metode Penelitian}

Dalam penelitian ini, penulis menggunakan metode deskriptif dengan pendekatan kualitatif. Metode penelitian kualitatif adalah penelitian yang digunakan untuk meneliti kondisi obyek yang bersifat alamiyah, (sebagai lawannya adalah eksperimen) sebagai instrument kunci, Nasution (dalam Sugiyono, 2014:61). Teknik pengumpulan data digunakan secara triangulasi data, analisis data bersifat 


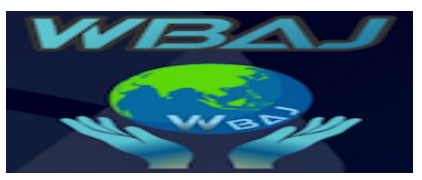

Volume 1 Issue 1, Juni 2019

http:// ejournal.unsub.ac.id/index.php/bisnis

induktif dan hasil penelitian kualitatif lebih menekankan kepada makna dari pada generalisasi, (sugiyono 2014:1). Tujuan penulis menggunakan metode deskriptif dengan pendekatan kualitatif adalah untuk memperoleh gambaran detil mengenai obyek yang diteliti. Dalam penelitian ini penulis mencoba mengungkapkan dan memahami fenomena apa yang terjadi terkait Seksi Usaha Ekonomi Masyarakat Dalam Pemberdayaan Pengelola Badan Usaha Milik Desa (BUMDES) Di Kabupaten Subang.

\section{Hasil dan Pembahasan}

Badan Usaha Milik Desa di Kabupaten Subang merupakan badan usaha yang seluruh atau sebagian besar modalnya dimiliki oleh desa melalui pernyataan secara langsung yang berasal dari kekayaan desa yang dipisahkan guna mengelola aset, jasa pelayanan dan usaha lainnya untuk sebesar-besarnya kesejahteraan masyarakat desa. Perlu adanya pengelolaan yang baik dan benar agar pengembangan badan usaha milik desa bisa terus berjalan atau meningkatkan perekonomian masyarakat desa. Untuk itu Pemerintah Daerah Kabupaten Subang melalui Dinas Pemberdayaan Masyarakat dan Desa bertanggung jawab memberikan layanan yang baik mengenai usaha ekonomi agar usaha ekonomi masyarakat di desa dapat meningkatkan perekonomiannya salah satunya melalui Badan Usaha Milik Desa (BUMDES) yang diharapkan mampu berjalan secara berkelanjutan agar potensi desa ada manfaatnya bagi masyarakat, sesuai dengan Visi Dinas Pemberdayaan Masyarakat dan Desa yaitu " Terwujudnya desa yang maju dan mandiri melalui peningkatan Pengelolaan Pemerintah Desa dan peningkatan Partisipasi Masyarakat Tahun 2023" dan Misinya mengenai Usaha Ekonomi Masyarakat "Mengembangkan Usaha Ekonomi Masyarakat, menggali potensi produk unggulan desa dan Keswadayaan masyarakat". Seksi Usaha Ekonomi Masyarakat merupakan salah satu seksi di bidang Pemberdayaan Usaha Ekonomi Masyarakat pada Dinas Pemberdayaan Masyarakat dan Desa yang yang diberikan tugas pokok fungsi dalam pelaksanan pemberdayaan pengelola Bumdes termasuk dalam memberikan pembinaan kepada pengelola Bumdes yang ada di Kabupaten Subang. Dalam mengukur Kinerja Seksi Usaha Ekonomi Masyarakat dalam Pemberdayaan Pengelola Badan Usaha Milik Desa (BUMDES) Di Kabupaten Subang, digunakan indikator kinerja organisasi menurut Dwiyanto (2012:50-51) ada lima indikator untuk mengukur kinerja organisasi yaitu produktivitas, kualitas layanan, responsivitas, responsibilitas dan akuntabilitas. Berdasarkan hasil wawancara dan observasi yang dilakukan di Dinas Pemberdayaan Masyarakat dan Desa Kabupaten Subang mengenai Kinerja Seksi Usaha Ekonomi Masyarakat dalam Pemberdayaan Pengelola Badan Usaha Milik Desa (BUMDES) di Kabupaten Subang, maka dapat digambarkan hasil penelitian sebagai berikut:

\section{Produktivitas}

Produktivitas didasarkan pada pendekatan multidisipliner yang secara efektif merumuskan tujuan, rencana, pengembangan dan pelaksanaan cara-cara yang produktif, dengan menggunakan sumber-sumber daya secara efisien namun tetap mempertahankan kualitas. Pada dasarnya produktivitas dipahami sebagai rasio 
antara input dan output. Mengidentifikasi tingkat efektivitas, efisiensi, pelayanan dan pelayanan publik untuk mencapai tujuan. Konsep produktivitas di rasa terlalu sempit dan kemudian General Accounting Office (GAO) mencoba mengembangkan satu ukuran produktivitas yang lebih luas dengan memasukkan seberapa besar pelayanan publik itu memiliki hasil yang di harapkan sebagai salah satu indikator kinerja yang penting. Dalam pemberdayaan pengelola Badan Usaha Milik Desa di Kabupaten Subang Dinas Pemberdayaan Masyarakat dan Desa melalui Seksi Usaha Ekonomi Masyarkat memiliki peran penting dalam memberikan pelayanan yang dibutuhkan oleh pemerintah desa dan pengelola Bumdes karena dengan adanya Bumdes menjadi salah satu upaya untuk meningkatkan perekonomiaan masyarakat desa. Namun pada kenyataannya saat ini tidak semua Bumdes di Kabupaten Subang maju atau eksis, hal ini dikarenakan faktor Sumber Daya Manusia (SDM) baik dari pemerintah desa maupun pengelola Bumdes sehingga membuat pengelolaan Bumdes tidak berkembang. Untuk itu dapat dilihat produktivitasnya dalam pemberdayaan pengelola Bumdes yang ada di Kabupaten Subang. Peneliti menemukan beberapa temuan mengenai pemberdayaan pengelola Bumdes di Kabupaten Subang terkait dengan produktivitas. Dalam hal ini penulis melakukan wawancara dengan Kepala Seksi Usaha Ekonomi Masyarakat, untuk mendapatkan informasi mengenai produktifitas seksi usaha ekonomi masyarakat dalam pemberdayaan pengelola Bumdes di Kabupaten Subang. Penulis mewawancarai Kepala Seksi Usaha Ekonomi Masyarakat Dinas Pemberdayaan Masyarakat dan Desa Kabupaten Subang pada tanggal 23 September 2019 mengenai realisasi pengembangan Bumdes di kabupaten Subang. Diperoleh pernyataan sebagai berikut : “Jumlah bumdes di kabupaten subang pada tahun 2018 yang terealisasi baru 154 dari data menunjukan 78 sudah aktif / eksis dan 76 masih dalam proses pembentukan dan sisanya 91 desa yang belum memiliki Bumdes. Sementara 30\% dari 78 Bumdes yang terdata di 30 Kecamatan kondisinya kembang kempis atau tidak berjalan. Nah untuk tahun sekarang kebanyakan Bumdes masih dalam pembentukan karena adanya pergantian kepala desa akan tetapi memang kalau dari target kita atau khususnya pemerintah daerah mengharapkan semua desa dari 245 desa di Kabupaten Subang memiliki satu desa satu bumdes akan tetapi kembali lagi kepada aturan yang ada bahwa desa harus memiliki Bumdes tergantung ada atau tidak potensi yang dimiliki desa tersebut". Penulis menyimpulkan Seksi Usaha Ekonomi Masyarakat belum melakukan kinerja terkait produktifitas sebagai mana dikatakan oleh informan di atas pencapaian pengembangan BUMDES di Kabupaten Subang ternyata belum seperti apa yang diharapkan. Dalam kenyataannya terdapat beberapa Bumdes dalam kondisi masih dalam proses pembentukan, belum berjalan dan belum terealisasi sesuai target. Seksi Usaha Ekonomi Masyarakat Dinas Pemberdayaan Masyarakat dan Desa belum melakukan Kinerja terkait Porduktivitas sebagai mana pernyataan di atas pemerintah belum melakukan peningkatan pengembangan Bumdes di desa-desa Kabupaten Subang sehingga kinerja Seksi Usaha Ekonomi Masyarakat belum optimal. Hal ini sebagaimana dilihat dari teori Produktivitas, yaitu mengembangkan satu ukuran produktivitas yang lebih luas dengan memasukkan seberapa besar pelayanan publik itu memiliki hasil yang di harapkan sebagai salah satu indikator kinerja yang penting. 
Penulis menyimpulkan pemerintah desa maupun pengelola Bumdes menilai SDM yang ada di Seksi Usaha Ekonomi Masyarakat Dinas Pemberdayaan Masyarakat dan Desa dalam pemberdayaan pengelola Bumdes sudah cukup. Dari penjelasan diatas, penulis menganalisis bahwa dalam pelaksanaan pemberdayaan pengelola Bumdes dilihat dari segi jumlah sumber daya manusia atau pegawai Seksi Usaha Ekonomi Masyarakat Dinas Pemberdayaan Masyarakat dan Desa masih mengalami kekurangan. Akan tetapi Dinas berkoordinasi dengan unit kerja terkait yaitu Tenaga Ahli Pendamping Ekonomi Desa (TA.PED) sehingga pemerintah desa maupun pengelola Bumdes menyatakan SDM Seksi Usaha Ekonomi Masyarakat Dinas Pemberdayaan Masyarakat dan Desa sudah cukup. Produktivitas sangat penting dalam suatu organisasi maka dari itu penulis mewawancarai Kepala Seksi Usaha Ekonomi Masyarakat mengenai sarana dan prasarana dalam pelaksanaan pemberdayaan pengelola Bumdes pada tanggal 23 September 2019 beliau mengemukakan bahwa : "Sarana prasarana sudah memadai karena di Bidang Usaha Ekonomi Masyarakat baik Kabid, Kasi dan staf rata-rata sudah memegang barang inventaris baik kendaraan roda 4 atau roda 2 dan sarana komputer dan leptop untuk menunjang kegiatan pemberdayaan pengelola bumdes termasuk untuk pembinaan atau pelatihan pengelola Bumdes"

Berdasarkan beberapa hasil wawancara di atas diketahui bahwa dimensi produktivitas belum berjalan dengan baik, hal itu terlihat dari realisasi yang belum sesuai dengan target, pelaksanaan pemberdayaan pengelola Bumdes belum sepenuhnya ditunjang dengan jumlah sumber daya manusia atau pegawai sehingga jumlah bumdes di kabupaten Subang belum terrealisasi dari yang telah direncanakan, masih ada Bumdes dalam kondisi tidak berjalan. Belum lagi pelaksanaan pemberdayaan pengelola Bumdes tidak tentu dilihat dari tidak ada jawal rutin dalam kegiatan pendampingan Bumdes yang sangat terbatasi tetapi memang dari Seksi Usaha Ekonomi Masyarakat Dinas Pemberdayaan Masyarakat dan Desa akan lebih memaksimalkan pendampingan untuk Bumdes.

\section{Kualitas Layanan}

Kualitas layanan merupakan bagian penting bagi masyarakat untuk melihat sejauh mana kinerja suatu organisasi publik. Orientasi kualitas layanan yang baik bisa dilihat dari kepuasan yang dirasakan oleh masyarakat itu sendiri, bagaimana organisasi sektor publik mampu memenuhi atau melayani segala kebutuhan yang dibutuhkan oleh masyarakat baik itu berupa sarana, prasarana, maupun kemudahan lainnya untuk memberikan kenpuasan untuk masyarakat. Kualitas layanan telah menjadi satu tahap faktor dominan terhadap keberhasilan suatu organisasi. Demikian pula dengan Seksi Usaha Ekonomi Masyarakat dalam memberikan pelayanannya kepada Badan Usaha Milik Desa (BUMDES) di Kabupaten Subang harus memberikan layanan yang baik sesuai dengan kebutuhan Bumdes maupun masyarakat desa. Tugas dan peran pemerintah daerah adalah melakukan sosialisasi tentang arti penting Bumdes bagi peningkatan kesejahteraan masyarakat, memfasilitasi dalam bentuk pelatihan atau pembinaan dan pemenuhan lainnya yang dapat memperlancar pendirian Bumdes. Selain sebagai fungsi fasilitator pemerintah daerah dan desa juga menjadi pemberi informasi kepada pengurus Bumdes, memonitoring dan mengevaluasi Bumdes. Informasi ke publik 


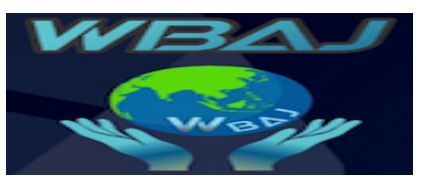

Volume 1 Issue 1, Juni 2019

http:// ejournal.unsub.ac.id/index.php/bisnis

merupakan hal yang sangat penting. Informasi adalah hasil pengolahan data yang memiliki arti atau manfaat bagi penerima. Pentingnya sebuah informasi dapat menunjukan berbagai hal yang diperlukan untuk menjalani suatu tugas atau kegiatan, atau untuk menentukan arah suatu tujuan rencana yang dikehendaki. Pemberian informasi oleh Seksi Usaha Ekonomi Masyarakat Dinas Pemberdayaan Masyarakat dan Desa Kabupaten Subang mengenai Pemberdayaan Bumdes menunjukan tentang pentingnya pembentukan Bumdes serta tata cara pengelolaan Bumdes yang benar. Dengan ini penulis melakukan wawancara dengan Kepala Seksi Usaha Ekonomi Masyarakat pada tanggal 23 September 2019, beliau mengatakan: "Untuk penyampaian informasi pemberdayaan Bumdes kami lakukan sosialisasi di minggon kecamatan. Kalau ada kegiatan lain seperti rapat Bumdes, pembinaan dll di Dinas ya melalui surat edaran atau WhatsApp biar lebih mudah."

Penulis menyimpulkan Sumber daya manusia/pegawai di seksi usaha ekonomi masyarkat sudah mampu menjalankan tugasnya walaupun keterbatasan pegawai tetapi Seksi Usaha Ekonomi Masyarakat berkoordinasi dengan unit kerja terkait yaitu Tenaga Ahli Pendamping Ekonomi Desa (TA.PED). Menurut pemerintah desa maupun pengelola Bumdes terkait kualitas sumber daya manusia Seksi Usaha Ekonomi Masyarakat Dinas Pemberdayaan Masyarakat dan Desa, mengatakan bahwa: "Kalau sumber daya manusianya itu tidak ada masalah bagi kami, iya sudah baguslah" (wawancara 1 Oktober 2019) Berdasarkan wawancara di atas, penulis menyimpulkan kualitas Sumber Daya Manusia Seksi Usaha Ekonomi Masyarakat Dinas Pemberdayaan Masyarakat dan Desa sudah sesuai atau mampu dalam menjalankan tugasnya karena mereka juga dibantu oleh Tenaga Ahli Pendamping Ekonomi Desa (TA.PED) dalam pelaksanaan pemberdayaan pengelola Bumdes di Kabupaten Subang. Hasil wawancara dengan Kepala Bidang Pemberdayaan Usaha Ekonomi Masyarakat, Beliau mengatakan bahwa: "Secara khusus kami tidak mempunyai SOP mengenai pemberdayaan pengelola Bumdes. Akan tetapi merujuk pada peraturan yang ada dan kami tetap berusaha memberikan pelayanan yang optimal dalam memenuhi kebutuhan dan keinginan dari pemerintah desa dan pengelola Bumdes." (wawancara 25 September 2019) Menurut Kepala Seksi Usaha Ekonomi Masyarakat, Beliau mengatakan bahwa: "Iya pasti sudah sesuai dan meningkatkan pelayanan yang sudah baik supaya BUMDES pada tiap-tiap desa yang sebagai wadah pembangunan ekonomi masyarakat bisa lebih maju dan bisa dirasakan keberadaannya oleh pemerintah desa maupun masyarakat desa tersebut". Bahwa untuk melaksanakan amanah undang-undang Nomor 25 tahun 2009 Tentang Penyelenggaraan Pelayanan publik wajib menyusun, menetapkan dan menerapkan standar pelayanan serta maklumat pelayanan dengan memperhatikan kemampuan penyelenggara, kebutuhan masyarakat dan kondisi lingkungan.

Berdasarkan wawancara di atas penulis menyimpulkan rata-rata Bumdes sedang bertumbuh memerlukan pendampingan dari berbagai pihak bukan hanya dari Seksi Usaha Ekonomi Masyarakat Dinas Pemberdayaan Masyarakat dan Desa saja. Hasil wawancara dengan Kepala Seksi Usaha Ekonomi Masyarakat: "Selalu mendorong dalam pertemuan dan pembinaan tersebut supaya keberadaan BUMDES yang sedang dibentuk atau sedang tumbuh dengan modal dukungan dari 
pemerintah desa lembaga desa dan para tokoh masyarakat BUMDES tersebut agar lebih maju" (wawancara 23 September 2019)

Berdasarkan hasil penelitian kualitas layanan yang diberikan Seksi Usaha Ekonomi Masyarakat dalam upaya pelaksanaan pengembangan BUMDES dapat mencapai target yang ditetapkan apabila didukung dengan penyediaan informasi yang lengkap, akurat dan mudah diperoleh. Untuk itu, Dinas Pemberdayaan Masyarakat dan Desa sebagai pelaksana dituntut agar dapat memberikan informasi dan sosialisasi dalam memotivasi dan memberikan pemahaman tentang pentingnya pengelolaan BUMDES untuk meningkatkan perekonomian masyarakat dan Desa. Berdasarkan analisa dan observasi, penulis menyimpulkan bahwa kualitas layanan yang diberikan Seksi Usaha Ekonomi Masyarakat dalam Pemberdayaan Pengelola BUMDES di Kabupaten Subang dapat dikatakan cukup baik. Sebagaimana penjelasan di atas terkait kualitas yang dimiliki oleh TA dan pegawai Seksi Usaha Ekonomi Masyarakat pada Dinas Pemberdayaan Masyarakat dan Desa Kabupaten Subang untuk melakukan pembinaan dalam rangka meningkatkan ekonomi masyarakat desa. Kualitas layanan merupakan ukuran citra yang diakui masyarakat mengenai pelayanan yang di berikan yaitu masyarakat merasa puas atau tidak puas. Berdasarkan analisa dan observasi, penulis menyimpulkan bahwa kualitas layanan yang diberikan Seksi Usaha Ekonomi Masyarakat dalam Pemberdayaan Pengelola BUMDES di Kabupaten Subang berupaya meningkatkan kinerja pelayanan dari segi informasi dan kualitas sumber daya dalam memberikan pembinaan pengelola Bumdes. Pemberian informasi kepada pemerintah desa maupum pengelola Bumdes sudah cukup baik yaitu melalui sosialisasi, sosial media (WhatsApp) dan surat edaran. Walaupun untuk sosialisasi yang dilakukan hanya di minggon kecamatan tidak langsung ke masyarkat desa. Sedangkan sumber daya manusia di Dinas Pemberdayaan Masyarakat dan Desa masih kekurangan pegawai. Akan tetapi Dinas Pemberdayaan Masyarakat dan Desa dibantu oleh TA.PED (Tenaga Ahli Pendaming Ekonomi Desa). Sehingga kualitas SDM dalam pemberdayaan pengelola Bumdes cukup baik. Yang menjadi kekurangan Seksi Usaha Ekonomi Masyarakat Dinas Pemberdayaan Masyarakat dan Desa dalam pelaksanaan pemberdayaan pengelola Bumdes yaitu tidak memiliki SOP.

\section{Responsivitas}

Responsivitas adalah kemampuan organisasi untuk menggali kebutuhan masyarakat, menyusun agenda prioritas pelayanan, mengembangkan programprogram pelayanan dan mengembangkan program-program pelayanan publik sesuai dengan kebutuhan dan aspirasi masyarakat. Responsivitas dimasukan sebagai salah satu indikator kinerja karena responsivitas secara langsung menggambarkan kemampuan organisasi publik dalam menjalankan misi dan tujuannya, terutama untuk memenuhi kebutuhan masyrakat. Kewajiban utama untuk melayani kepentingan publik bagaimana harus mengedepankan kepentingan dan kesejahteraan masyarakat diatas kepentingan pribadi. Hal ini berkaitan dengan kemampuan untuk mengetahui dan memahami kebutuhan maupun keinginan masyarakat pengguna jasa sehingga pelayanan yang diberikan oleh dinas pemberdayaan masyarakat dan desa sesuai dengan yang diinginkan oleh pemerintah desa dan pengelola bumdes dan mampu memenuhi kepuasan 


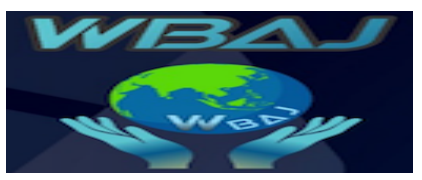

Volume 1 Issue 1, Juni 2019

http:// ejournal.unsub.ac.id/index.php/bisnis

masyarakat. Wawancara dengan Kepala Seksi Usaha Ekonomi Masyarakat, Beliau mengatakan bahwa: "Kami semaksimal mungkin untuk memberikan pelayanan kepada pemerintah desa dan pengelola Bumdes dengan baik. Ketika pemerintah desa atau pengelola Bumdes menyampaikan keluhan kami selalu memberikan masukan, motivasi, merespon dengan menanyakan apa yang mereka inginkan. Dan jika kami tidak bisa melakukan sesuai harapan pemerintah desa atau pengelola Bumdes iya itu keterbatasan kami. Tapi jika terkait pembinaan kami akan memberikan pelayanan yang prima." (wawancara 23 September 2019) Senada dengan Kepala Seksi Bina Pemasran produk unggulan di Dinas Pemberdayaan Masyarakat dan Desa, mengatakan : "Terkait Bumdes dinas pasti melakuan yang terbaik untuk bisa melayani sesuai apa yang dibutuhkan desa-desa tersebut dan kalau Desa membutuhkan atau mengundang kami pasti ke desa datang menghadiri." (wawancara 23 September 2019) Berdasarkan hasil wawancara di atas bahwa responsivitas atau kemampuan Seksi Usaha Ekonomi Masyarakat Dinas Pemberdayaan Masyrakat dan Desa Kabupaten Subang dalam menangani kebutuhan pemerintah desa atau Pengelola Bumdes sudah cukup baik. Hal tersebut terlihat dari kepekaan Dinas Pemberdayaan Masyarakat dan Desa kepada pemerintah desa maupun pengelola Bumdes yang menyampaikan keluhan dan melayani dengan baik sehingga terlihat bahwa Seksi Usaha Ekonomi Masyarakat Dinas Pemberdayaan Masyarakat dan Desa Kabupaten Subang sudah cukup responsif di dalam mengenali kebutuhan pemerintah desa dan pengelola Bumdes. Dalam hal ini penulis mewawancarai Kepala Seksi Usaha Ekonomi Masyarakat Dinas Pemberdayaan Masyarakat dan Desa Kabupaten Subang mengenai prosedur apa yang dilakukan jika ingin melakukan sosialisasi pemberdayaan pengelola Bumdes yang sesuai dengan kebijakan atau prinsip-prinsip administrasi yang telah ditentukan. Beliau mengungkapkan bahwa: "Melaksanakan sesuai dengan tupoksi kita Seksi Usaha Ekonomi Masyarakat Dinas Pemberdayaan Masyarakat dan Desa Kabupaten Subang khususnya dalam kegiatan BUMDES di Desa-desa sebagaimana atas dasar-dasar Permendes, Perbup tentang pembinaan BUMDES" (wawancara 23 September 2019). Berdasarkan hasil wawancara penulis dengan Kepala Seksi Usaha Ekonomi Masyarakat Dinas Pemberdayaan Masyarakat dan Desa Kabupaten Subang sudah sesuai yang di harapkan oleh penulis. sesuai dengan dimensi Resposivitas kemampuan organisasi untuk menggali kebutuhan masyarakat, menyusun agenda dan prioritas pelayanan dan mengembangkan program program pelayanan publik sesuai dengan kebutuhan dan aspirasi masyarakat.

\section{Responsibilitas}

Responsibilitas menjelaskan apakah pelaksanaan kegiatan organisasi publik itu dilakukan sesuai dengan prinsip-prinsip administrasi yang benar atau sesuai dengan kebijakan organisasi baik itu berupa suatu sanksi maupun tindakan lainnya. Sehingga dalam pelaksanaan pelayanan pemberdayaan pengelola Bumdes tidak terjadi kesalahan atau melanggar aturan yang ada. Untuk melihat sejauhmana responsibilitas para pegawai dalam pemberdayaan pengelola Bumdes baik dalam pelaksanaan maupun penerapan sanksi peneliti melakuan wawancara pada dinas terkait. Penulis melakukan wawancara dengan Kepala Bidang Pemberdayaan Usaha Ekonomi Masyarakat, Beliau mengungkapkan bahwa : "Belum sesuai 
dengan Peraturan Bupati yang berlaku, yang mengatur tentang tupoksi dari Dinas Pemberdayaan Masyarakat dan desa itu sendiri, dilihat dari pelaksanaan monitoring dan evaluasi yang hanya dilakukan sementara waktu" Berdasarakan hasil wawancarai penulis dengan Kepala Bidang Pemberdayaan Usaha Ekonomi Masyarakat masih belum sesuai dengan peraturan yang berlaku yang mengatur tentang tugas pokok dan fungsi dinas pemberdayaan masyarakat dan desa kabupaten subang ini sesuai dengan peraturan Bupati no 66 Tahun 2016 dimana salah satu tugasnya adalah melaksanakan monitoring dan evaluasi pengembangan Bumdes. Penulis mewawancarai TA.PED (Tenaga Ahli Pemberdayaan Ekonomi Desa) Beliau mengungkapkan bahwa : "Melaksanakan, jadi setiap bulan itu minimal 5 bulan sekali jadi antara sebulan itu 50\% kita koordinasi dengan Dinas 50\% ke lapangan jadi setiap bulan ada. Dinas pun sama." (wawancara 23 September 2019) Berdasarkan temuan di lapangan penulis menyimpulkan bahwa TA.PED sudah sesuai yang di harapkan terkait Penjadawalan koordinasi dalam pemberdayaan pengelola Bumdes dengan Dinas Pemberdayaan Masyarakat dan Desa. Penulis wawancarai dengan Kepala Bidang Pemberdayaan Usaha Ekonomi Masyarakat, Beliau mengatakan bahwa : "Kita sebagai organisasi publik yang harus selalu memberikan pelayanan yang maksimal terhadap kebutuhan masyarakat, dalam hal ini pemberdayaan pengelola Bumdes tentu saja segala sesuatunya harus sesuai dengan aturan yang telah ditetapkan. Meski kita belum ada SOP yang khusus dalam pemberdayaan pengelola Bumdes di Kabupaten Subang. Adapun sanksi yang kita terapkan hanya berupa teguran dan penjelasaan kepada pemerintah Desa dan pengelola Bumdes. Kami telah bekerja keras untuk menegakan aturan yang ada." (wawancara 23 September 2019). Berdasarkan wawancara di atas, dapat penulis simpulkan terkait pelaksanaan monitoring dan evaluasi Bumdes yang dilakukan Seksi Usaha Ekonomi Masyarakat Dinas Pemberdayaan Masyarakat dan Desa belum sepenuhnya dilakukan dilihat dari masih adanya Bumdes yang belum di monitoring dan evaluasi. Berdasarkan temuan di lapangan penulis menyimpulkan bahwa pelaksanaan pemberdaayan pengelolaan Bumdes yang di lakukan seksi usaha ekonomi masyarakat sudah optimal hal ini dapat dilihat dari hasil wawancara di atas. Sesuai dengan hasil observasi dan hasil wawancara penulis menyimpulkan bahwa responsibilitas Seksi Usaha Ekonomi Masyarakat belum sesuai dengan peraturan yang berlaku yang mengatur tentang tugas pokok dan fungsi Dinas Pemberdayaan Masyarakat dan Desa Kabupaten Subang ini sesuai dengan peraturan Bupati no 66 Tahun 2016 tentang tugas pokok dan fungsi dimana salah satu tugasnya adalah melaksanakan monitoring dan evaluasi pengembangan Bumdes dan tidak adanya SOP di Dinas Pemberdayaan Masyarkat dan Desa terkait pemberdaaan pengelolaan Bumdes.

\section{Akuntabilitas}

Akuntabilitas merujuk pada seberapa besar kebijakan dan kegiatan organisasi publik tersebut konsisten dengan kehendak masyarakat banyak. Kinerja organisasi publik tidak hanya bisa dilihat dari ukuran internal yang dikembangkan oleh organisasi publik atau pemerintah, seperti pencapaian target. Kinerja sebaiknya harus dinilai dari ukuran eksternal, seperti nilai-nilai dan norma yang berlaku dalam masyarakat. Suatu kegiatan organisasi publik memiliki akuntabilitas tinggi 


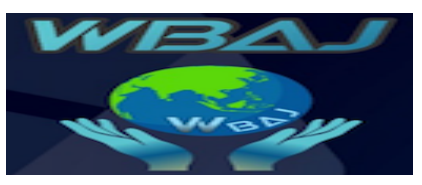

Volume 1 Issue 1, Juni 2019

http:// ejournal.unsub.ac.id/index.php/bisnis

jika kegiatan itu dianggap benar dan sesuai dengan nilai dan norma yang berkembang dalam masyarakat dan dirasakan manfaat dari kegiatan tersebut. Dapat dikatakan bahwa akuntabilitas merupakan suatu unsur yang terpenting untuk mewujudkan suatu sistem pemerintahan yang bersih dan baik. Dengan adanya akuntabilitas akan mendorong pegawai untuk melaksanakan tugas dan tanggungjawabnya. Dengan adanya tanggungjawab bahwa seorang pegawai dapat mampu mengabdikan dirinya pada bangsa dan masyarakat. Pemerintah wajib mempertanggungjawabkan kegiatan/program yang berkaitan dengan pelaksanaan APBN/APBD, baik dalam bentuk laporan keuangan maupun laporan kinerja. Laoran keuangan disusun dan disajikan sesuai dengan Standar Akuntansi Pemerintah (SAP), sedangkan laporan kinerja disusun sesuai dengan peraturan pemerintah yang mengatur tentang laporan kinerja intansi pemerintah. Untuk mengetahui akuntabilitas Seksi Usaha Ekonomi Msayarakat Dinas Pemberdayaan Masyarakat dan Desa Kabupaten Subang maka dilihat dari cara atau atau mekanisme pertanggungjawaban yang dilakukan. Berdasarkan hasil wawancara dengan Kepala Seksi Usaha Ekonomi Masyarakat, mengatakan bahwa: “Mekanisme pertanggungjawaban harus dibedakan yaitu keuangan dan program/kegiatan. Pertanggungjawaban keuangan berdasarkan peraturan tentang pengelolaan keuangan daerah, sedangkan SKPD Berdasarkan perda APBD yang dituangkan dalam penjabaran APBD Kabupaten Subang. Seksi Usaha Ekonomi Masyarakat melalui Bidang Pemberdayaan Usaha Ekonomi Masyarakat mempertanggungjawabkan kegiatan sesuai dengan yang tercantum dalam DPA melalui pelaporan perbulan atau pertahun. Laporan keuangan maupun fisik dilakuakan secara berkala dan isinya dapat dilihat dari program/ kegiatan yang terrealisasi. Sedangkan untuk akhir tahun yaitu laporan akuntabilitas kinerja intansi pemerintah (LAKIP/LKJIP). LAKIP disususn dan dibuat pada akhir tahun sebagai bagian dari pertanggungjawaban pelaksana program/kegiatan." Adapun salah satu bentuk pertanggung jawaban Seksi Usaha Ekonomi Masyarakat Berdasarkan hasil wawancara dengan pemerintah desa maupun pengelola Bumdes diketahui bahwa Pemerintah Desa baik pengelola Bumdes membutuhkan banyak informasi serta laporan kegiatan sejauhmana kegiatan pemberdayaan pengelola Bumdes berjalan karena pemerintah desa maupun baik pengelola Bumdes berhak tahu kemana dan bagaimana itu berjalan.

\section{Kesimpulan}

Produktivitas Seksi Usaha Ekonomi Masyarakat belum optimal dilihat dari jumlah Bumdes yang belum terealisasi sesuai target. Direncanakan semua Desa atau 245 Desa yang ada di Kabupaten Subang harus memiliki Bumdes akan tetapi yang terealisasi hanya 154 dan itu pun dalam kondisi 78 aktif, 76 dalam proses pembetukan maka yang belum memiliki Bumdes 91 Desa. Ditambah dinas keterbatasan Sumber Daya Manusia (SDM).

Pelayanan yang diberikan Seksi Usaha Ekonomi Masyarakat pada Dinas Pemberdayaan Masyarakat dan Desa sudah cukup baik terlihat dari pemberian informasi dengan melalui surat edaran, WhatsApp dan sosialisasi. Akan tetapi sosialisasi yang dilakukan hanya melalui minggon kecamatan tidak langsung ke 


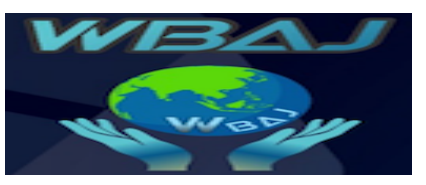

Volume 1 Issue 1, Juni 2019

http:// ejournal.unsub.ac.id/index.php/bisnis

desa-desa sehingga ada sebagian BUMDES yang sudah terbentuk tetapi pengelolaannya belum berjalan. Ditambah Seksi Usaha Ekonomi Masyarakat Dinas Pemberdayaan Masyarakat dan Desa dalam pelaksanaan pemberdayaan pengelola Bumdes tidak memiliki SOP.

Daya tanggap Seksi Usaha Ekonomi Masyarakat masih belum sepenuhnya optimal karena walaupun dari dinas selalu berusaha menanggapi dengan memberikan motivasi kepada Bumdes akan tetapi masih ada Bumdes dalam kondisi tidak berjalan sehingga tidak ada kegiatan di dalam pengelola Bumdes dan tidak memberikan dampak terhadap ekonomi masarakat.

Pertanggunjawaban Seksi Usaha Ekonomi Masyarakat yang belum baik ialah dalam pelaksanaan monitoring dan evaluasi yang hanya dilakukan sementara waktu dan tidak langsung ke Bumdes yang ada di desa-desa Kabupaten Subang. Pertanggung jawaban yang dilakukan oleh Seksi Usaha Ekonomi Masyarakat masih kurang, seperti keterlambatan dalam penyelesaian laporan dan pertanggung jawaban yang dilaporkan hanya pada Pemerintah Kabupaten saja tidak ada transparsnsi kepada Pemeintah Desa maupun pengelola Bumdes.

\section{Referensi}

Armosudiro Pradjudi, 2006. Konsep Organisasi. Jakarta: PT Raja Grafindo Persada

Bugin, 2012. Penelitian Kualitatif. Jakarta: Kencana Perdana Grafika.

Creswell, J.W. 2010. Design Research: Pendekatan Kualitatif, Kuantitatif, dan Mixed. Yogyakarta: Pustaka Pelajar.

Dwiyanto, Agus, 2012. Reformasi Birokrasi Publik di Indonesia. Yogyakarta: Gajah Mada University Press.

Fahmi, Irham. 2010. Manajemen Kinerja, Teori dan Aplikasi. Bandung: Alfabeta.

Idrus, Muhammad. 2009. Metode Penelitian Sosial Pendekatan Kualitatif dan Kuantitatif. Jakarta: Erlangga.

Indrawijaya. 2006. Perilaku Organisasi. Jakarta: Sinar Baru

Keban, Yeremias T, 2005, Enam Dimensi Strategis Administrasi publik: Konsep, Teori dan Isu,. Yogyakarta: Penerbit Gaya Media.

Mahmudi. 2013. Manajemen Kinerja Sektor Publik, Edisi Kedua. Yogyakarta: Unit Penerbit dan Percetakan Sekolah Tinggi Ilmu Manajemen YKPN.

Miles dan Huberman, 1994, Qualitative Data Analysis, diterjemahkan Tjetjep Rohendi, Analisis Data Kualitatif, Jakarta : UI Press.

Moeheriono, 2010, Pengukuran Kinerja Berbasis Kompetensi, Ghalia Indonesia, Bogor.

Moeheriono, 2012, Indikator Kinerja Utama (IKU), Jakarta Rajawali Pers PT. Raja Grafindo Persada 


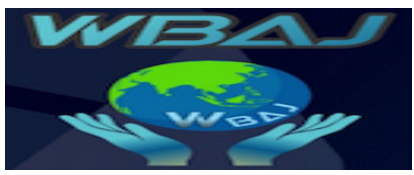

Moleong, L. 2007. Metodologi Penelitian Kualitatif. Bandung : PT. Remaja Rosada Karya.

Pasolong, Harbani. 2011. Teori Administrasi Publik. Bandung: Alfabeta

Peraturan Bupati Subang Nomor 13 Tahun 2017 tentang Pembentukan dan Pengelolaan Badan Usaha Milik Desa.

Simanora, Henry, 2004. Manajemen Sumberdaya Manusia. Yogyakarta : Bagian Penerbitan STIE YPKN.

Sedarmayanti, 2001, Sumber Daya Manusia dan Produktifitas Kinerja, Bandung : Mandar maju.

Sudarmanto, 2009, Kinerja dan Pengembangan Kompetensi SDM, Yogyakarta : Pustaka Pelajar.

Surya Dharma, Manajemen Kinerja, Yogyakarta : Pustaka Pelajar.

Sugiyono, 2014, Memahami Penelitian Kualitatif. Bandung: Alfabeta.

Sugiyono, 2008. Metode Penelitian Administrasi. Bandung: Alfabeta.

Surjadi, 2009. Pengembangan Kinerja Pelayanan Publik. Bandung: Refika Aditama.

Tangkillisin, Hassel Nogi. 2005. Manajemen Publik. Jakarta: PT. Gramedia Widiasarana Indonesia.

Ulum, Ihyaul. 2009. Audit Sektor Publik. Jakarta: Bumi Aksara.

Wibowo, 2016. Manajemen Kinerja. Jakarta. Penerbit: PT Raja Grafindo Persada. 